\title{
PERLINDUNGAN KONSUMEN TERKAIT PEMBATALAN SECARA SEPIHAK VOUCHER HOTEL OLEH PELAKU USAHA TRAVELOKA*
}

\author{
Oleh: \\ Made Bella Meisya Prihantini** \\ I Wayan Parsa** \\ Program Kekhususan Hukum Bisnis, Fakultas Hukum, \\ Universitas Udayana
}

\begin{abstract}
ABSTRAK
Kegiatan perdagangan di masyarakat berkembang pesat seiring berkembangnya teknologi komunikasi dan internet. Segala kegiatan manusia dalam bidang berusaha lebih dipermudah. Secara khusus dalam perusahaan travel yang menyediakan pemesanan tiket pesawat maupun voucher hotel secara online melalui aplikasi dalam smartphone. Pernah terjadi pembatalan voucher hotel secara sepihak oleh Traveloka yang menyebabkan terjadinya kerugian bagi konsumen. Untuk itu perlu dicari kejelasan perlindungan hukum terkait hak-hak konsumen dalam Undang-Undang Nomor 8 Tahun 1999 Tentang Perlindungan Konsumen.

Metode penelitian yang digunakan dalam jurnal ini yaitu metode penelitian empiris dengan melihat kesenjangan dari berlakunya teori dengan praktek yang terjadi di dalam lingkungan masyarakat.

Hasil penelitian menunjukan bahwa Pelaku Usaha Traveloka memberikan tanggung jawab berdasarkan wanprestasi (breach of warranty) yang berupa ganti kerugian dari voucher hotel yang dibatalkan. Tujuan dari penulisan jurnal ini yaitu mengetahui perlindungan hukum bagi konsumen terkait pembatalan secara sepihak voucher hotel oleh pelaku usaha Traveloka.
\end{abstract}

Kata Kunci: Perlindungan Konsumen, Pembatalan Sepihak.

\footnotetext{
ABSTRACT

Commercial activites are rapidly growing during development of technology and internet. All kind of human activities related to

${ }^{*}$ Penulisan karya ilmiah yang berjudul "Perlindungan Konsumen Terkait Pembatalan Secara Sepihak Voucher Hotel Oleh Pelaku Usaha Traveloka" ini merupakan ringkasan di luar skripsi.

** Made Bella Meisya Prihantini adalah Mahasiswa Fakultas Hukum Universitas Udayana, bmeisya@ymail.com.

${ }^{* * *}$ I Wayan Parsa adalah Dosen Fakultas Hukum Universitas Udayana.
} 
working field became so easy. Specially for travel company that provides online based tickets for plane and hotel through smartphone application. There were one sided hotel voucher cancellation by traveloka that caused a costs to the consumer. Therefore, it is necessary to find clarity of consumer right based on Law Number 8 Year 1999 about Consumer Protection.

Research method that been used in this journal is empirical by seeing a gap between theory compared to reality that happened in the society life.

Research result show that the responsibility of the Traveloka give breach of warranty responsibilities in the form of compensation from canceled hotel vouchers. This journal attempted to discover the law enforcement for the related consumer who had been through one sided cancellation by Traveloka.

\section{Keyword: Consumer Protection, Unilateral Cancellation.}

\section{PENDAHULUAN}

\subsection{Latar Belakang Masalah}

Berkembangnya perekonomian dengan pesat di masyarakat menghasilkan ragam jenis transaksi barang maupun jasa bagi konsumen. Hal ini menimbulkan secara otomatis bahwa tanggung jawab sosial yang dimiliki oleh konsumen menjadikan kewajiban dari perusahaan itu sendiri guna mendapatkan kepercayaan dari public atau masyarakat umum. ${ }^{1}$ Perlindungan terhadap konsumen menjadi pandangan penting, dikarenakan berkembangnya produktivitas dan efisiensi produsen dalam mencapai sasaran usaha berkaitan erat dengan meningkatnya globlalisasi. 2 Masyarakat konsumen berhak mendapatkan perlindungan hukum dari pemerintah apabila terjadinya pelanggaran yang merugikannya. Pemerintah Indonesia telah mengeluarkan kebijakan pengaturan hak-hak konsumen melalui pembentukan undang-undang yaitu UUPK. ${ }^{3}$

${ }^{1}$ Zulham, 2016, Hukum Perlindungan Konsumen, Kencana, Jakarta, h. 4.

${ }^{2}$ Celina Tri Siwi Kristiyanti, 2017, Hukum Perlindungan Konsumen, Sinar Grafika, Jakarta, h. 5.

${ }^{3}$ Zulham, op. Cit., h. 6. 
Dewasa ini, masyarakat Indonesia dipermudah dengan adanya pembelian tiket pesawat maupun pemesanan hotel secara online. Pemesanan dapat diakses oleh setiap lapisan masyarakat dengan mengakses aplikasi melalui smartphone. Pemesanan hotel dilakukan tanpa adanya tatap muka antara pelaku usaha dengan konsumen. Dalam melakukan pemesanan, konsumen cukup mengakses melalui aplikasi online perusahaan travel tersebut (Traveloka), selanjutnya memilih hotel yang diinginkan, disesuaikan dengan tanggal check in, jumlah hari menginap, serta total tamu dan kamar yang diperlukan. Selanjutnya akan muncul ketersediaan hotel yang ditampilkan oleh aplikasi tersebut yang kemudian diisi oleh data diri pribadi pemesan untuk kemudian setelah di transfernya total pembayaran yang sebelumnya dapat dipilih metode pembayaran mana yang akan dipilih konsumen untuk melakukan pembayaran dalam durasi waktu 48 menit. Apabila pembayaran sudah terkonfirmasi dan dilakukan sesuai dengan sebelum habisnya durasi waktu maka voucher hotel akan terbit sesuai data diri pribadi pemesan yang sudah diisi tersebut.

Pada tanggal 21 Juni 2017 pukul 10.00 wita, Dessy Suastini melakukan pemesanan hotel (Bali Lovina Beach Cottages) sebanyak 3 kamar deluxe untuk tanggal 30 Juni 2017 secara online melalui aplikasi Traveloka dan melakukan pembayaran pada pukul 10.15 wita di hari yang sama melalui SMS Banking Mandiri ke Nomor Rekening Mandiri dengan Nama Pemilik Rekening PT. Trinusa Travelindo sesuai petunjuk aplikasi Traveloka dengan nomor pemesanan 349014771. Kemudian, pada pukul 10.25 pembayaran telah dikonfirmasi dan voucher hotel tersebut telah terbit. Namun pada tanggal 26 Juni 2017 pihak Traveloka menginformasikan melalui email bahwa terjadi pembatalan voucher hotel untuk pemesanan hotel (Bali Lovina 
Beach Cottages) sebanyak 3 kamar deluxe untuk tanggal 30 Juni 2017 secara sepihak. Konsumen sesungguhnya telah memenuhi aturan pemesanan yang disampaikan oleh aplikasi travel tersebut dan memesan sesuai ketersediaan yang disampaikan oleh aplikasi travel tersebut. Namun secara sepihak, Traveloka membatalkan voucher tersebut dikarenakan pihak hotel baru menyampaikan bahwa tidak terdapat ketersediaan kamar hotel deluxe di tanggal tersebut. Pihak Traveloka dalam hal ini tidak dapat memenuhi kewajibannya sehingga merugikan konsumen karena pembatalan voucher hotel disampaikan setelah pembayaran dan penerbitan voucher hotel yang sudah diselesaikan dan diterbitkan setelah 5 hari pemesanan. Berdasarkan pengalaman tersebutlah penulis tertarik untuk membahas perlindungan konsumen terkait pembatalan secara sepihak voucher hotel tersebut oleh Pelaku Usaha Traveloka.

\subsection{Rumusan Masalah}

1. Bagaimanakah bentuk tanggung jawab dari Pelaku Usaha Traveloka terkait pembatalan secara sepihak voucher hotel tersebut?

2. Upaya hukum apakah yang dapat dilakukan bagi konsumen yang dirugikan akibat pembatalan voucher hotel secara sepihak?

\subsection{Tujuan Penelitian}

Tujuan dari jurnal ini yaitu mengetahui bentuk tanggung jawab Traveloka terkait kerugian yang didapatkan oleh konsumen dalam pembatalan voucher hotel dan perlindungan hukum yang diperoleh konsumen terkait pembatalan secara sepihak voucher hotel oleh Traveloka tersebut menurut UUPK.

\section{ISI MAKALAH}

\subsection{Metode Penelitian}


Metode yang digunakan dalam penyusunan jurnal ini yaitu penelitian hukum secara empiris dengan menggunakan objek kajian membandingkan ketentuan hukum normatif (undangundang) dengan implementasinya pada setiap peristiwa hukum yang terjadi di lingkungan masyarakat. ${ }^{4}$ Sehingga penelitian ini meliputi kesenjangan dalam teori dengan prakteknya dalam masyarakat.

\subsection{Hasil dan Analisis}

\subsubsection{Tanggung Jawab Pelaku Usaha Traveloka Terkait Pembatalan Secara Sepihak Voucher Hotel}

Traveloka merupakan salah satu perusahaan travel yang menyediakan layanan kamar hotel, pemesanan tiket pesawat, dan berbagai macam jenisnya dengan fokus perjalanan domestik dan internasional. Adapun dua platform yang dimiliki oleh Traveloka yaitu dengan basis data web yang dapat diakses melalui Personal Computer dan dengan basis data aplikasi yang dapat diakses melalui gadget dengan memiliki Operating System seperti Android maupun Apple. Menurut Situs yang memberi review Traveloka, Traveloka memiliki beberapa kelebihan dibanding travel agent online sejenisnya yang salah satunya yaitu tiket pesawat maupun kamar hotel yang ditawarkan oleh Traveloka tidak dibebankan dengan harga booking maupun service fee di setiap pemesanan tiketnya.

Kelebihan itulah yang mengakibatkan Traveloka dianggap lebih murah, dan dapat dikatakan menggunakan traveloka lebih mudah karena berbagai macamnya metode pembayaran yang dapat dilakukan dalam pesanan yang dapat dipilih sesuai keinginan yaitu berbagai macam jenis Bank yang dapat diakses melalui setor tunai, transfer ATM, e-banking, maupun m-banking.

${ }^{4}$ Abdulkadir Muhammad, 2004, Hukum \& Penelitian Hukum, Citra Aditya Bakti, Bandung, h. 134. 
Serta Traveloka disebut sebagai agen perjalanan yang lebih terpercaya dikarenakan dalam sistemnya waktu untuk pembayaran tiket akan muncul secara otomatis ketika kita melakukan pemesanan, kemudian apabila dalam waktu yang telah ditentukan pelanggan tidak melakukan pembayaran maka pesanan akan otomatis terblokir oleh sistem.

Secara umum hubungan hukum antara produsen dengan konsumen merupakan hubungan yang terus-menerus dan berkesinambungan. Hubungan hukum antara produsen dengan konsumen karena keduanya menghendaki dan mempunyai tingkat ketergantungan yang cukup tinggi. Hubungan tersebut terjadi sejak proses produksi, distribusi, pemasaran dan penawaran hingga pada akibat mengonsumsi produk tersebut. ${ }^{5}$ Konsumen Dessy Suastini yang melakukan transaksi dengan pelaku usaha Traveloka secara sah telah membentuk perjanjian yang mengikat para pihaknya. Dalam Pasal 1320 KUHPerdata disebutkan syaratsyarat sahnya perjanjian yang terdiri dari empat syarat yaitu: (1)Kesepakatan bagi mereka yang membuat perjanjian; (2)Kecakapan daripada pihak yang membuat perjanjian; (3)Suatu pokok persoalan tertentu; dan (4)Suatu sebab yang tidak terlarang. Yang kemudian, persetujuan yang dibuat kedua belah pihak berlaku sebagai Undang-Undang bagi para pihak yang membuatnya. Persetujuan tersebut tidak dapat ditarik kembali selain dengan kesepakatan kedua belah pihak, serta persetujuan tersebut harus dilaksanakan dengan itikad baik sesuai dengan Pasal 1338 KUHPerdata.

UUPK mengakomodasikan dua prinsip penting, yakni tanggung jawab produk (product liability) dan tanggung jawab profesional (professional liability). Tanggung jawab produk

${ }^{5}$ Ahmadi Miru, 2017, Prinsip-Prinsip Perlindungan Hukum Bagi Konsumen Di Indonesia, Rajawali Pers, Jakarta, h. 36. 
merupakan tanggung jawab produsen untuk produk yang dipasarkan kepada pemakai, yang menimbulkan dan menyebabkan kerugian karena cacat yang melekat pada produk tersebut. Sedangkan tanggung jawab professional berhubungan dengan jasa, yakni tanggung jawab produsen terkait dengan jasa professional yang diberikan kepada klien. ${ }^{6}$ Kerugian yang diterima oleh konsumen disini terjadi karena pelanggaran berupa tidak terpenuhinya perjanjian yang sudah diperjanjikan yang dilakukan oleh pelaku usaha dengan pihak konsumennya, hal ini dapat disebut dengan sengketa konsumen. Shidarta menyebutkan sengketa konsumen merupakan sengketa yang meliputi semua segi hukum baik dalam keperdataan, pidana maupun tata negara dengan pelanggarannya terhadap hak-hak konsumen. ${ }^{7}$

Dalam perlindungan konsumen dikenal tiga prinsip tanggung jawab yaitu prinsip tanggung jawab berdasarkan kelalaian atau kesalahan (negligence), prinsip tanggung jawab berdasarkan wanprestasi (breach of warranty) dan prinsip tanggung jawab mutlak (strict product liability). Dalam hal ini prinsip tanggung jawab yang digunakan yaitu Tanggung Jawab berdasarkan wanprestasi (breach of warranty). Tanggung jawab produsen berdasarkan wanprestasi juga merupakan bagian dari tanggung jawab berdasarkan kontrak (contractual liability). Apabila terdapat kerugian yang diterima oleh konsumen yang diakibatkan tidak terpenuhinya kewajiban oleh produsen berdasarkan isi

${ }^{6}$ Shidarta, 2006, Hukum Perlidungan Konsumen Indonesia, Grasindo, Jakarta, h.80.

${ }^{7}$ Nata Wibawa, 2018, "Perlindungan Hukum terhadap Konsumen terkait Peredaran Mie Instan Kadaluwarsa di Kota Denpasar" Jurnal Fakultas Hukum Universitas Udayana Bali, Vol. 06 No. 03 Th. 2018, h. 6. 
perjanjian baik tertulis maupun tidak tertulis maka sudah menjadi kewajiban bagi produsennya untuk memberikan ganti kerugian. ${ }^{8}$

Pihak Traveloka dalam hal ini tidak memenuhi kewajibannya selaku pelaku usaha dalam perjanjian jual beli tersebut karena melakukan pembatalan secara sepihak. Sehingga dapat dikatakan Traveloka melakukan perbuatan wanprestasi. Pengertian mengenai wanprestasi menurut Munir Fuady (default/non fulfillment/breach of contract) yaitu tidak terwujudnya prestasi yang menjadi kewajibannya yang dibebankan dan terdapat di dalam kontrak bagi pihak-pihak yang terlibat dalam kontrak tersebut. Menurut Salim H.S mengartikan wanprestasi sebagai tidak terpenuhinya antara kreditur dengan debitur suatu kewajiban sebagaimana yang terdapat dan telah dibentuk bersama dalam perjanjian yang dibuat. ${ }^{9}$ Dalam Pasal 1266 ayat 1 KUHPer menyebutkan bahwa syarat batal dianggap ketika salah satu pihak dalam perjanjian tidak memenuhi kewajibannya yang telah disepakati bersama atau wanprestasi selalu terdapat dalam perjanjian yang bertimbal balik. ${ }^{10}$

Dalam pasal 19 UUPK menyebutkan mengenai tanggung jawab yang dimiliki oleh pelaku usaha, meliputi tuntutan ganti kerugian yang diajukan oleh konsumen sebagai akibat dari digunakannya produk, baik yang meliputi kerugian dalam bentuk materi, fisik maupun jiwa. Tuntutan disini dalam dua kategori, meliputi tuntutan ganti kerugian yang diakibatkan karena wanprestasi dan didasarkan pada perbuatan melanggar hukum yang dilakukan oleh pelaku usaha. Sehingga, Traveloka memiliki

${ }^{8}$ Ahmadi Miru, 2004, Hukum Perlindungan Konsumen, PT rajagrafindo Persada, Jakarta, h. 148.

9 Bagus Hanindyo Mantri, 2007, "Perlindungan Hukum Terhadap Konsumen Dalam Transaksi E-Commerce" Tesis Program Magister Ilmu Hukum, Universitas Diponegoro, h. 16.

${ }^{10}$ Suharnoko, 2008, Hukum Perjanjian Teori dan Analisa Kasus, Kencana, Jakarta, h. 65. 
kewajiban untuk bertanggung jawab dengan menanggung ganti kerugian yang diderita oleh konsumen akibat pembatalan voucher hotel tersebut.

Berdasarkan hasil wawancara dengan Dessy Suastini selaku konsumen bahwa diketahui Traveloka telah memberi ganti kerugian berupa uang. Ini diketahui berdasarkan email yang dikirimkan terhadap konsumen mengenai pembatalan voucher hotel tersebut, pihak Traveloka akan merefund total pembayaran yang dilakukan oleh konsumen melalui akun rekening Bank Central Asia. Apabila konsumen memberikan nomor rekening bank lain maka total pembayaran akan dikurangi sesuai dengan biaya charge yang dikenakan antar bank. Sehingga kerugian tetap didapatkan oleh konsumen tersebut walaupun nominalnya tidak banyak.

\subsubsection{Upaya Hukum Yang Dapat Dilakukan Bagi Konsumen} Yang Dirugikan Akibat Pembatalan Voucher Hotel Secara

\section{Sepihak}

Perlindungan hukum yang dimiliki oleh masyarakat Indonesia merupakan bagian dari hak asasi manusia berdasarkan ketentuan hukum maupun kebijakan hukum yang wajib diberikan oleh pemerintah sebagai jaminan hak konstitusional warga negara guna menjamin kepastian hukum, keadilan, serta kemanfaatan seluruh warga negara berdasarkan Pancasila dan UUD NRI 1945. ${ }^{11}$ Perlindungan hukum dapat diartikan sebagai suatu perlindungan yang dikeluarkan oleh perangkat hukum yang bersifat preventif maupun represif, baik yang tertulis maupun tidak tertulis yang didapatkan setiap subjek hukum. Oleh karena

${ }^{11}$ Cahyadi, 2018, "Pelaksanaan Perlindungan Hukum Untuk Konsumen terhadap Peredaran Makanan Yang Telah Kadaluwarsa di Pasar Kereneng Denpasar", Jurnal Fakultas Hukum Universitas Udayana Bali, Vol. 06 No. 03 Th. 2018, h. 5. 
itu perlindungan hukum merupakan konsep dimana hukum dapat memberikan suatu keadilan, ketertiban, kepastian, kemanfaatan dan kedamaian yang meliputi dari fungsi hukum.

Johanes Gunawan menyebutkan bahwa setiap konsumen akan memperoleh perlindungan hukum pada saat sebelum maupun setelah terjadinya transaksi dengan pelaku usaha. Adapun konsumen yang memperoleh perlindungan hukum di saat sebelum terjadinya transaksi dapat dilakukan dengan cara; (1)Legislation, yaitu perlindungan hukum terhadap konsumen yang dilakukan sebelum terjadinya transaksi dengan perlindungan yang diberikan berdasarkan peraturan perundang-undangan berlaku. Dengan adanya peraturan perundang-undangan berlaku secara sah maka perlindungan akan diperoleh sebelum adanya transaksi seperti batasan-batasan dan ketentuan yang mengatur transaksi antara konsumen dan pelaku usaha yang diperoleh oleh konsumen; (2) Voluntary Self Regulation, yaitu konsumen akan memperoleh perlindungan hukum sebelum terjadinya transaksi, sehingga diharuskan secara sukarela pelaku usaha membentuk suatu peraturan yang berhati-hati dan waspada bagi dirinya sendiri dalam menjalankan usahanya. ${ }^{12}$

Dalam Black's Law Dictionary mendefinisikan a statue that safeguards consumers in the use goods and services. Perlindungan konsumen merupakan bentuk perlindungan hukum dari hal-hal yang merugikan kepentingan dari konsumen itu sendiri yang diberikan dan wajib didapatkan kepada pihak konsumen dalam usahanya dalam mewujudkan kebutuhan. ${ }^{13}$ Berdasarkan UUPK, perlindungan konsumen yaitu berbagai upaya yang memberi jaminan kepastian hukum untuk memberikan perlindungan kepada setiap konsumen. Sehingga, adanya perlindungan 
konsumen ini penting adanya untuk mengatasi kerugian yang diterima oleh konsumen akibat dari pembatalan secara sepihak yang dilakukan oleh Pelaku Usaha Traveloka tersebut.

Berdasarkan hak-hak konsumen yang terdapat dalam Pasal 4 UUPK, salah satunya menjelaskan bahwa hak untuk memperoleh ganti kerugian bagi kosumen. Kemudian yang dimaksudkan untuk menyelesaikan keadaan tidak seimbang akibat adanya pembatalan voucher hotel secara sepihak oleh pelaku usaha Traveloka terhadap konsumen, dalam merealisasikan hak yang dimiliki oleh konsumen ini melalui tahapan tertentu, meliputi penyelesaian secara damai, negosiasi (di luar pengadilan) ataupun dengan penyelesaian di pengadilan. ${ }^{14}$

Dibatalkannya voucher hotel secara sepihak oleh Traveloka selaku pelaku usaha juga dikarenakan alasan yang disampaikan karena tidak adanya ketersediaan kamar hotel setelah voucher diterbitkan. Ini berarti termasuk dalam ketentuan pasal 9 ayat (1) huruf e UUPK, mengenai dilarangnya bagi pelaku usaha untuk memberikan tawaran, promosi maupun iklan terhadap suatu jasa secara tidak benar, seolah-olah jasa tersebut tersedia. Yang berarti Traveloka memenuhi unsur dalam pasal mengenai larangan yang dilakukan oleh pelaku usaha karena menawarkan kamar hotel kepada konsumen yang sesungguhnya ketersediaan kamar hotel tersebut tidak ada.

Dalam Pasal 16 huruf a UUPPK, menyebutkan tidak menepati pesanan dan/atau kesepakatan waktu penyelesaian sesuai dengan yang dijanjikan. Unsur larangan yang terdapat dalam pasal tersebut memenuhi perbuatan pembatalan secara sepihak oleh traveloka yaitu pelaku usaha traveloka tidak menepati pesanan yang diperjanjikan terhadap konsumennya.

${ }^{14}$ Ahmadi Miru \& Sutarman Yodo, 2015, Hukum Perlindungan Konsumen Edisi Revisi, Raja Grafindo Persada, Jakarta, h. 44. 
Perbuatan yang dilakukan oleh Traveloka disini dapat dituntut berdasarkan perbuatan tidak menepati janji atau wanprestasi khususnya dapat dipidana oleh aparat yang berwenang sesuai dengan prosedur yang berlaku. ${ }^{15}$

Berdasarkan UUPK upaya hukum yang dapat ditempuh atas kerugian yang didapatkan oleh konsumen akibat pembatalan voucher hotel secara sepihak tersebut dapat diselesaikan melalui dua cara yaitu Penyelesaian sengketa melalui pengadilan (litigasi) dan Penyelesaian sengketa di luar Pengadilan (non litigasi) atau yang lebih dikenal dengan Alternative Dispute Resolution (ADR). Penyelesaian sengketa melalui pengadilan (litigasi) disebutkan dalam Pasal 48 UUPK, yaitu penyelesaian sengketa melalui pengadilan hanya dimungkinkan dilakukan apabila para pihak belum memilih upaya penyelesaian sengketa konsumen di luar pengadilan atau upaya penyelesaian sengketa di luar pengadilan dinyatakan tidak berhasil oleh salah satu pihak atau oleh para pihak yang bersengketa. ${ }^{16}$

Penyelesaian sengketa di luar pengadilan (non litigasi) dapat ditempuh dengan berbagai cara, meliputi arbitrase, mediasi, konsiliasi, minitral, negosiasi, summary jury trial, settlement conference serta bentuk lainnya. ${ }^{17}$ Konsumen yang ingin melakukan penyelesaian sengketa secara non-litigasi ini dapat dilakukan dengan jalur alternative dispute resolution (ADR) ke Badan Penyelesian Sengketa Konsumen (BPSK), Lembaga Perlindungan Konsumen Swadaya Masyarakat (LPKSM), Direktorat Perlindungan Konsumen di bawah Departemen Perdagangan, atau lembaga-lembaga lain yang berwenang. ${ }^{18}$ Penyelesaian sengketa

\footnotetext{
15Ibid., h. 102-103.

${ }^{16}$ Ibid., h. 238.

${ }^{17}$ Ibid., h. 237

18Happy Sutanso, 2008, Hak-Hak Konsumen Jika Dirugikan, Transmedia
} Pustaka, Jakarta, h.77. 
secara damai dengan mediasi merupakan cara penyelesaian yang fleksibel dan tidak mengikat pihak netral, yaitu mediator yang bertugas mempermudah negosiasi antara pihak untuk membantu mereka dalam mencapai kesepakatan. ${ }^{19}$

Kemudian upaya hukum yang digunakan oleh Traveloka dalam menyelesaikan sengketanya dengan konsumen yaitu Dessy Suastini berdasarkan hasil wawancara adalah dengan cara non litigasi yaitu negosiasi. Negosiasi dilakukan dengan tujuan mencapai kesepakatan bersama mengenai sama besar dan bentuknya ganti rugi dan/atau tindakan tertentu yang menjamin tidak terulangnya lagi kerugian yang dialami oleh konsumen. Adapun hasil dari negosiasi tersebut berupa ganti kerugian yang diberikan oleh Traveloka dalam bentuk uang.

\section{PENUTUP}

\subsection{Kesimpulan}

Berdasarkan pembahasan diatas, maka kesimpulan yang dapat diambil meliputi:

1. Tanggung jawab yang diberikan pelaku usaha Traveloka terkait kerugian yang diperoleh konsumen dalam pembatalan voucher hotel tersebut didasarkan dalam prinsip Tanggung Jawab berdasarkan Wanprestasi (breach of warranty). Sesuai dalam Pasal 19 UUPK yaitu bertanggung jawab dengan memberi ganti kerugian yang diderita oleh konsumen. Fakta di lapangan menyebutkan, Dessy Suastini selaku konsumen telah menerima ganti kerugian tersebut berupa uang. Namun kerugian kecil tetap diterima oleh konsumen dikarenakan Traveloka hanya memberikan pilihan Bank Central Asia sebagai nomor rekening yang

19 Ibid., h. 163. 
akan direfund, apabila bank lain maka traveloka akan mengurangi dengan biaya charge antar bank.

2. Perlindungan hukum bagi konsumen terkait pembatalan secara sepihak voucher hotel oleh pelaku usaha Traveloka terdapat dalam Pasal 4, Pasal 9 dan Pasal 16 UUPK. Sehingga upaya hukum yang ditempuh berdasarkan UUPK atas kerugian yang didapatkan oleh konsumen dapat ditempuh secara litigasi dan non-litigasi. Berdasarkan fakta yang diperoleh, upaya hukum yang ditempuh adalah non litigasi yaitu dengan negosisasi antara pihak Traveloka dan Dessy Suastini selaku konsumen.

\subsection{Saran}

Sebaiknya Traveloka sebagai perusahaan travel yang menyediakan layanan pemesanan hotel lebih teliti dengan tidak menampilkan pilihan pemesanan hotel yang sesungguhnya tidak terdapat ketersediaannya dari pihak hotel sendiri. Sehingga tidak akan memberikan kerugian bagi konsumen seperti pembatalan secara sepihak yang diakibatkan oleh Traveloka sendiri. Dan seharusnya pelaku usaha Traveloka tidak memberikan kerugian kecil sekalipun terhadap konsumen karena pembatalan yang diakibatkannya sendiri, sehingga perlu adanya dalam klausula baku apabila terjadi pembatalan secara sepihak oleh pelaku usaha Traveloka, untuk tidak memberi kerugian sedikitpun.

\section{DAFTAR PUSTAKA}

\section{Buku}

Kristiyanti, Celina Tri Siwi, 2017, Hukum Perlindungan Konsumen, Sinar Grafika, Jakarta.

Miru, Ahmadi dan Sutarman Yodo, 2015, Hukum Perlindungan Konsumen Edisi Revisi, Raja Grafindo Persada, Jakarta.

Miru, Ahmadi, 2004, Hukum Perlindungan Konsumen, PT RajaGrafindo Persada, Jakarta. 
Miru, Ahmadi, 2017, Prinsip-Prinsip Perlindungan Hukum Bagi Konsumen Di Indonesia, Rajawali Pers, Jakarta.

Muhammad, Abdulkadir, 2004, Hukum dan Penelitian Hukum, Citra Aditya Bakti, Bandung.

Shidarta, 2006, Hukum Perlindungan Konsumen Indonesia, Grasindo, Jakarta.

Suharnoko, 2008, Hukum Perjanjian Teori dan Analisa Kasus, Kencana, Jakarta.

Sutanso, Happy, 2008, Hak-Hak Konsumen Jika Dirugikan, Transmedia Pustaka, Jakarta.

Zulham, 2016, Hukum Perlindungan Konsumen, Kencana, Jakarta.

\section{Tesis}

Mantri, Bagus Hanindyo, 2007, "Perlindungan Hukum Terhadap Konsumen Dalam Transaksi E-Commerce" Tesis Program Magister Ilmu Hukum, Universitas Diponegoro.

\section{Jurnal Ilmiah}

Wibawa, Nata, 2018, "Perlindungan Hukum terhadap Konsumen terkait Peredaran Mie Instan Kadaluwarsa di Kota Denpasar" Jurnal Fakultas Hukum Universitas Udayana Bali, Vol. 06 No. 03 Th. 2018.

Cahyadi, 2018, "Pelaksanaan Perlindungan Hukum Bagi Konsumen terhadap Peredaran Makanan Yang Telah Kadaluwarsa di Pasar Kereneng Denpasar", Jurnal Fakultas Hukum Universitas Udayana Bali, Vol. 06 No. 03 Th. 2018.

\section{Peraturan Perundang-Undangan}

UUD NRI Tahun 1945

Undang-undang Nomor 8 Tahun 1999 Tentang Perlindungan Konsumen (LNRI Nomor 42 Tahun 1999)

Kitab Undang Undang Hukum Perdata 